\title{
Descriptive Analysis of Filariasis Occurances in Baktiya And Nisam Sub-Districts Aceh Utara District In 2017
}

\author{
Cut Khairunnisa ${ }^{1,2}$ \\ \{cut.khairunnisa@unimal.ac.id\} \\ ${ }^{1} \mathrm{PhD}$ Student of Faculty of Public Health, Universitas Sumatera Utara, Medan, Indonesia \\ ${ }^{2}$ Department of Public Health, Faculty of Medicine, Universitas Malikussaleh, Aceh, Indonesia
}

\begin{abstract}
The three provinces in Indonesia with the highest number of filariasis cases are Aceh, East Nusa Tenggara and Papua. In the province of Aceh, the district with the highest number of filariasis cases is Aceh Utara District. This research takes an approach of observational research with descriptive design. The samples taken were total population of filariasis patients in two subdistricts, Baktiya and Nisam Sub-district, Aceh Utara District with 35 cases. The result of research showed that most filariasis patients were 60 years old, predominantly male patient with 54,3\% and majorily possessed junior high school as their highest level of education, 48,8\%. Most often encountered behavior associated with filariasis occurrence is outdoors gers at night by $54.3 \%$ and not using anti-mosquito repellent of $68.6 \%$. Positive behavior encountered was the habit of using bed nets during sleep by $62.9 \%$, and the habit of wearing clothes and trousers by $57.1 \%$. The physical and outdoor environments found are not using of wire screening of $80 \%$, poor ceiling conditions of $77.1 \%, 77.4 \%$ of hanging items at home, $80 \%$ poor waste water sewer condition conditions and the presence of paddy fields and shrubs, bushes around the house of $88.6 \%$.
\end{abstract}

Keywords: Baktiya, deskriptive analysis, filariasis, nisam

\section{INTRODUCTION}

Filariasis or elephantiasis is an infectious disease caused by filarial worms mediated by mosquito vectors [1]. The worms live in the lymph channels. At an advanced stage, it can cause permanent disability in the form of leg, arm, breast and genitalia, both in men and women [2]. The World Health Organization (WHO) has identified filariasis as a major cause of disability worldwide [3]. WHO data show that filariasis has infected 120 million people in 83 countries around the world, especially in tropical and subtropical regions. There are three types of filariasis parasites within the SEAR (South-East Asia) region, namely Wuchereria bancrofti, Brugia malayi and Brugia timori. The parasites can be found in 9 countries, namely Bangladesh, India, Indonesia, Maldive, Myanmar, Nepal, Sri Lanka, Thailand and Timor Leste [4].

Filariasis cases occur almost evenly throughout Indonesia causing it still as a health problem in Indonesia. In some parts of Indonesia, filariasis has a relatively high endemic level 
[5]. Overall, there was 11.914 filariasis chronic cases reported by districts / municipalities until 2009. The three provinces with the highest number of filariasis cases are Aceh Province with 2,359 cases, East Nusa Tenggara with 1,730 cases and Papua with 1,158 cases. When compared with other provinces, the incidence of filariasis in Aceh Province is very prominent and rank as top province with filariasis cases throughout Indonesia. Within the Aceh province, Aceh Utara is the district with the highest number of filariasis cases with a total of 1,353 clinicalcases [6].

Aceh Utara was declared an endemic district of elephantiasis (filariasis) disease. The disease caused by the bites of all the mosquitoes continues to increase. Residents of the disease are scattered in a number of districts. Head of Aceh Utara Health Office Machrozal said, most elephantiasis patients found in Baktiya Sub-District with as many as 24 cases and Nisam Sub-District with as many as 11 cases. The rest of residents are spread out in Langkahan Sub-district and other sub-districts. Generally, elephantiasis patients occur at the aged over 45 years [7].

Based on the above data which show districts with highest cases of filariasis, it is necessary to handle the case to cease it's increase. The first step in the handling process is to identify the factors that influence the incidence of filariasis. Many risk factors trigger filariasis incidence. Some of these are host factors, socioeconomic, behavioral and environmental factors. Environmental factors include indoor and outdoor environment. Indoor environmental factors include the physical environment of houses that do not meet the criteria of healthy homes, such as house construction and wall, lighting, and humidity, so as to trigger filariasis incidence [8].

\section{LITERATURE REVIEW}

\subsection{Definition of Filariasis}

Filariasis (elephantiasis disease) is a chronic disease caused by filarial worms and is transmitted by Mansonia, Anopheles, Culex, Armigeres mosquitoes. The worms live in the lymph and lymph nodes with acute clinical manifestations of recurrent fevers, inflammation of the lymph and lymphatic ducts. At an advanced stage, it can cause permanent disability of leg, arm, breast and genital enlargement [9].

\subsection{Etiologi}

Lymphatic filariasis is caused by Wuchereria bancrofti, Brugia malayi and Brugia timori which can live exclusively in the human body. Worms are in the lymphatic system on the "tissue" between the lymph vessels and blood vessels that maintain the body fluid balance and are essential components for the body's immune defense system. Worms stay alive for 4-6 years and produce larvae (microfilariae) which will blend in blood circulation [10].

Filariasis is also caused by Loa loa, Onchocerca volvulus, Acanthocheilonema perstants, Mansonella azzardi. However, the three most important species are W.bancrofti, B. malayi and B. timori [11].

Up to this point of time, 23 species of mosquitoes of genus for filariasis vector in Indonesia has been found namely: Mansonia, Anopheles, Culex, Aedes and Armigeres. There are ten species of Anopheles mosquitoes identified as vectors of the rural Wuchereria bancrofti. The urban-type Wuchereria bancrofti vector is Culex quinquefasciatus. Six species 
of Mansonia are vectors of Brugia malayi. In eastern Indonesia, Mansonia and Anopheles barbirostris are important phialariasis vectors. Some species of Mansonia may become vectors of Brugia malayi type sub periodic nocturna. While Anopheles barbirostris is an important vector against Brugia timori located in Nusa Tenggara Timur and Maluku Selatan islands [4].

\subsection{Clinical Manifestation}

Clinical symptoms among patients vary widely, ranging from asymptomatic to severe. This depends on the geographic area, the parasitic species, the patient's immune response, and the intensity of the infection. Symptoms usually appear after 3 months of infection but generally bud between 8-12 months. Lymphatic inflammation symptoms occur in the acute phase, while obstruction occurs in the chronic phase. The acute phase is characterized by fever or a series of febrile attacks over several weeks. Even though the fever is usually not too high, it may reach up up to $40.6^{\circ} \mathrm{C}$. This condition is accompanied by chills and sweats, headache, nausea, vomiting, and muscle aches. Should the parasites attack abdominal lymph nodes, it starts to develop "acute abdomen" symptoms [9].

\subsection{Filariasis Risk Factor}

1. Host Factor, consist of humans and mosquitoes: the human factor is strongly influenced by age, sex and immunity. The mosquito factor is influenced by the behavior of mosquitoes, the frequency of human biting and the genotrophic cycle needed to ripen the egg [12].

2. Environmental factors, namely (1) physical environment in the form of air temperature, humidity, wind, rain, sunshine, water flow, mosquito breeding, house wall conditions, installation of wire mesh, (2) biological environment is the occurrence of filariasis transmission. Examples of biological environments are the presence of aquatic plants, puddles, swamps, and bushes as a place for the growth of mosquito Mansonia spp. (3) the social, economic and cultural environment is the environment that arises as a result of interaction among human beings, including the behavior, customs, culture, customs and traditions of the population. Like the habit of going out, the use of mosquito nets and antimosquito repellent, work and education [13].

\subsection{Target for Elimination and Definition of Lymphatic Filariasis}

Although parasites can be detected microscopically in the blood, thorough approaches to filariasis elimination are relatively difficult. The primary prevention for the case is to protect from mosquito bites in endemic areas. WHO has established a Global Agreement, namely The Global Goal of Elimination of Lymphatic Filariasis as a Public Health problem by The Year 2020 to combat filariasis disease thoroughly (Haryuningtyas and Subekti, 2004). The program carried out a mass treatment with a combination of diethyl carbamazine (DEC) and albendazole (Alb) recommended once a year for five years. Indonesia carried out elephantiasis disease gradually to commence in 2002.

Strategic plan 2010-2020 The target for elimination of lymphatic filariasis was based on the status of control in countries and published in the Progress report 2000-2009 and strategic plan 2010-2020 (1) of the Global Programme to Eliminate Lymphatic Filariasis in World Health Organization, 2013. 
Table 1. Targets in the Global Programme to Eliminate Lymphatic Filariasis for interrupting transmission in endemic countries, by year

\begin{tabular}{ccccc}
\hline YEAR & \multicolumn{4}{c}{ CATEGORY (OBJECTIVE) } \\
\hline $\begin{array}{c}\text { Starting } \\
\text { implementation } \\
\text { begun) }\end{array}$ & $\begin{array}{c}\text { Scaling up } \\
\text { MDA }\end{array}$ & $\begin{array}{c}\text { Stopping interventions and } \\
\text { starting surveillance }\end{array}$ & $\begin{array}{c}\text { Verifying absence of } \\
\text { transmission }\end{array}$ \\
\hline 2012 & 85 & 70 & 25 & 20 \\
2014 & 100 & 75 & 40 & 20 \\
2016 & 100 & 100 & 70 & 40 \\
2018 & 100 & 100 & 75 & 75 \\
2020 & 100 & 100 & 100 & 70 \\
\hline
\end{tabular}

\section{METHODS}

This research is an observational research with descriptive design. The samples taken were total population of filariasis patients in two sub-districts, Baktiya and Nisam Sub-district, Aceh Utara District with 35 cases. Using questionnaires, researcher interviewed audience to analyze factors causing filariasis occurrence of host factors in the form of age and gender, socioeconomic factors (level of education) and behavior. In addition, observation was also carried around the respondent's residence or sample to understand the physical condition environment of the patients. The data obtained in this study will be univariatally analyzed to describe the factors that play a role in filariasis incidence in Baktiya and Nisam Sub-Districts.

\section{RESULT AND DISCUSSION}

This research was conducted in Baktiya and Nisam Sub-Districts Aceh Utara District in 2017. Baktiya and Nisam two sub-districts in Aceh Utara District with the highest number of filariasis cases and are filariasis endemic areas. Baktiya and Nisam Sub-Districts is agricultural area with plenty of rice fields, plantations and swamps. People here rely their lives from farming and gardening.

Table 2. Respondent distribution by age.

\begin{tabular}{ccccc}
\hline No & Mean & Median & Modus & Min-max \\
\hline 1. & 57,60 & 60 & 60 & $35-80$ \\
\hline
\end{tabular}

Table 2 illustrates the average age of filriasis patients is 57.6 years, the youngest age was 35 years and the oldest age was 80 years old. All ages have comparable chance of contracting filariasis. However, in the case of Baktiya and Nisam sub-districts, filariasis cases were found only in adults. The findings of filariasis cases in these two sub-districts were prompted accidentally as they sought for treatment for their illness and was not the result of the examination conducted by the health service or the puskesmas. Filariasis is hard to detect, but the transmission is slow. Age is one of the risk factors of filariasis. It attacks in all age groups. Basically everyone can catch filariasis when infected by infective mosquitoes (containing 
stage 3 larvae) thousands of times [4]. Often times, patients seek new treatments when their disease has been chronic and their limbs has been smelling [14].

Table 3. Distribution of Gender of Respondents

\begin{tabular}{llcc}
\hline No & Gender & Number & Percentase \\
\hline 1. & Male & 19 & 54,3 \\
2. & Female & 16 & 45,7 \\
\hline & Total & 35 & 100 \\
\hline
\end{tabular}

Table 3 elucidated that men are more predisposed to filariasis by 19 people $(54.3 \%)$. This fact may br trigerred by many of male habit in the region to be out at night. This has increased possibility being infected with filariasis. This research is in accordance with research conducted by Triwibowo Ambar in sub-district of Ampibabo Sulawesi tengah who found the number of filariasis patients in men is $52.66 \%$ [15]. This study is also in accordance with the results of further analysis Riskesdas conducted Santoso who found filariasis patients in men more than women [16].

Table 4. Distribution of respondent level of education

\begin{tabular}{llcc}
\hline No & Level of Education & Number & Percentase \\
\hline 1. & Primary school graduate & 15 & 42,9 \\
2. & Junior high school graduate & 17 & 48,6 \\
3. & Senior high school graduate & 3 & 8,6 \\
\hline \multicolumn{2}{l}{ Total } & 35 & 100 \\
\hline
\end{tabular}

Table 4 shows that most people suffering from filariasis attained junior high school education level $(48.6 \%)$ and elementary school (42.9\%). None were found with undergraduate degree education. Therefore, it can be concluded that the average filariasis patients in Baktiya and Nisam sub-districts are poorly educated. Low education closes tightly with knowledge. Generally, people with low education levels result in low knowledge and difficulty receiving and understanding information, in this case, knowledge and information relating to health problems. Research conducted by Ike Ani in southern pekalongan also found filariasis patients found in low education of $33.8 \%$ of elementary school graduates and $25 \%$ of junior high school graduates [17].

Table 5 shows that most filariasis patients have the habits to be out of their homes at night $54.3 \%$. This habit results in exposure to vector contact [13]. Mosquito Culex sp likes to suck human and animal blood, especially at night [18]. In Acehnese culture, many men enjoy being outdoor during night time to gather with friends or other people. This habit may also exist as social activities such as attending the event of death (Takziah), weddings, village deliberations, or gathering at a coffee shop until late at night. A study conducted by Puji Juriastuti found that Respondents who have a habit of going out at night have a 5.4 times greater chance of developing filariasis disease than those who do not [19].

Table 5. Respondent Behavior

\begin{tabular}{llcc}
\hline No & Behavior & Number & Percentase \\
\hline 1. & $\begin{array}{l}\text { Habits to be out at night } \\
\text { a. Yes }\end{array}$ & 19 & 54,3 \\
\hline
\end{tabular}




\begin{tabular}{llcc}
\hline No & Behavior & Number & Percentase \\
\hline 2. & b. No & 16 & 45,7 \\
& Habit of utilizing mosquito net when sleeping & & \\
a. Yes & 22 & 62,9 \\
b. No & 13 & 37,1 \\
3. Habits of using mosquito repellant & & \\
& a. Yes & 11 & 31,4 \\
b. No & 24 & 68,6 \\
4. Habits of wearing shirt and tro users & & \\
a.Yes & 20 & 57,1 \\
b. No & 15 & 42,9 \\
\hline
\end{tabular}

Communities in Baktiya and Nisam sub-districts have a habit of using mosquito nets during sleep at night by $62.9 \%$. This is one positive thing that respondents have done to avoid contact with mosquitoes during sleep. The use of mosquito nets is very effective and useful to prevent contact with mosquitoes. However, such habit is meaningless if not performed routinely. Theoritically, the habit of wearing mosquito nets at bedtime has contributed to the prevention of filariasis, as the bitings at their highest at night time [20].

Table 5 explained that most of the people do not use anti-mosquito repellent $68.8 \%$. Mosquito repellent not only used during sleep, but also at night before bed or during community or family gathenring to prevent mosquito bites. Although most of them used mosquito nets when sleeping, not many use mosquito repellents. Anti-mosquito repellent is one of the efforts to protect themselves from mosquito bites and easily applied, either in the form of anti-mosquito burned, sprayed, or on topical. But this anti-mosquito repellent would not be effective if its use is not at peak hours of mosquito population density or respondents have a habit of going out at night [21].

Another positive thing in the behavior of respondents is the habit of using clothes and trousers. From the interview, 57.1\% of respondent wear clothes. Aceh is an Islamic Shari'ah area, so the use of clothing and trousers (covered dress) especially for women is an obligation for the people of Aceh. The use of these clothes and trousers can minimize contact with mosquitoes.

Table 6. Physical environment and outdoor overview

\begin{tabular}{|c|c|c|c|}
\hline No & Physical environment and outdoor & Number & Percentase \\
\hline \multirow[t]{3}{*}{1.} & Use of gauze & & \\
\hline & a. Yes & 7 & 20 \\
\hline & b. No & 28 & 80 \\
\hline \multirow[t]{3}{*}{2.} & Ceiling condition & & \\
\hline & a. Poor & 27 & 77,1 \\
\hline & b. Good & 8 & 22,9 \\
\hline \multirow[t]{3}{*}{3.} & Hanging items all over the house & & \\
\hline & a. Yes & 25 & 71,4 \\
\hline & b. No & 10 & 28,6 \\
\hline \multirow[t]{3}{*}{4.} & Waste water sewer & & \\
\hline & a. Poor & 28 & 80 \\
\hline & b. Good & 7 & 20 \\
\hline \multirow[t]{3}{*}{5.} & Existance of rice fields or bushes & & \\
\hline & a. Available & 31 & 88,6 \\
\hline & b. Not available & 4 & 11,4 \\
\hline
\end{tabular}


Table 6 illustrated the physical condition of the respondent's house, from 35 samples of $80 \%$ of the respondent's house did not use the wire gauze on the ventilation, this makes it very easy for mosquitoes to enter the house. Research conducted Juriastuti found that respondents who do not have wire gauze at home at risk 7.2 times greater suffering from filariasis than respondents who install gauze. Installation of gauze wire in the ventilation will decrease contact of mosquitoes that are outside the house with the occupants of the house, where mosquitoes cannot enter the house [19]. According to Davey the use of gauze in ventilation can reduce the contact between Anopheles and human mosquitoes [22].

Most of the physical condition of respondent's house has poor condition of ceiling that is equal to $77,1 \%$. Ceiling serves as meaningful separator between the precarious and the room so as not to connect directly. Thus, it can be concluded that the ceiling is necessary to create partition and prevent mosquitoes to freely enter the house [19].

Environmental conditions outside the home or around respondent houses are shown in table $5.80 \%$ of the houses have poor sewerage channels. These conditions resulted in the large number of wastewater puddles around the respondent's home. As mosquitoes uses water for their life cycle, these puddles can become a place for the mosquito breeding. Shortage of breeding water will cut off their growth. Once spawned an adult mosquito can produce \pm 100 300 grains, with a size of about $0.5 \mathrm{~mm}$. After 1-2 days the egg will hatch so larvae, 8-10 days become cocoon (pupa), and 1-2 days into adult mosquito [23]. Mardiana et al study found that house with open sewage can have 2.56 times more risk for filariasis than the closed ones. This suggests that filariasis occur in poor sewerage conditions or inadequate health is associated with filariasis [20].

Respondents' house surroundings which were mainly located near the rice fields and bushes, $88.6 \%$, also added to the matter. These places increased the breeding ground for the mosquitoes. Research conducted by Ansari found that the proportion of filariasis in people whose home is close to the mosquito habitat can reach 8 times. This was due to the proximity with the puddles near the house which also serve as the breeding places for Cx mosquitoes. Quinquefasciatus to carry out its life cycle, although the volume of water is small. In addition, as most mosquitoes flying distance is generally ranges from 1 to $2 \mathrm{~km}$, brings thems closer to humans [24].

\section{5 conclusion}

In conclusion, filariasis disease in Baktiya and Nisam sub-districts is experienced mostly by male people aged 60. Most people who suffer filariasis have low levels of education. Most dominant habit of filariasis patients associated with filariasis occurrence was the habits of being out door during night time and low use of antimosquito repellant. Physical and external environmental factors supporting the increase in filariasis are the absence of wire netting (gauze) in ventilation, poor ceiling conditions, the hanging items within the house, poor waste water sewer conditions, and the presence of rice fields and shrubs in around the house.

Considering numerous filariasis risk factors available, it is imperative to do Filariasis mitigation comprehensively by taking the mechanism of Epidemiological approach into account; Risk Areas Stratification, Clinical Case Management and Treatment of Patients including Promotion Elimination efforts. Mass drug prevention of Filariasis is expected to break filariasis transmission chain. Sufficient and comprehensive understanding of the 
magnitude and risk factors that affect it are vital in order to eliminate filariasis. A control program may transpire in the form of surveillance to find patients with acute and chronic elephantiasis and carry out treatment to enable the patients to take care of themselves.

\section{REFERENCES}

[1] Ministry of Health of the Republic of Indonesia, "Menuju Eliminasi Filariasis 2020." Kementerian Kesehatan RI, 2015.

[2] A. Ardias, O. Setiani, and Y. H. Darundiati, "Environmental and Community Behavior Factor Associated With The Incidence of Filariasis in Sambas District," J. Kesehat. Lingkung. Indones., vol. 11, no. 2, pp. 199-207, 2012.

[3] M. Brian F Lich, "Filariasis Practice Essentials, Background, Pathophysiology," 2017.

[4] Ministry of Health of the Republic of Indonesia, "Peraturan Menteri Kesehatan Repubik Indonesia Nomor 94 tahun 2014, tentang Penanggulangan Filariasis." pp. 1-118, 2014.

[5] R. Amelia, "Analysis Risk Factors of Filariasis Insidence," Unnes J. Public Heal., vol. 3, no. 1, pp. 1-10, 2014.

[6] Ministry of Health of the Republic of Indonesia, "Filariasis in Indonesia," Bul. Jendela Epidemiol., vol. 1, no. 1, pp. 15-19, 2010.

[7] Masriadi, "Aceh Utara Declared Endemic of Elephantiasis Disease," Kompas, 2015. .

[8] H. M. Laumalay, "Study of Endemicity and Risk Factors of Filariasis in Sumba Barat Regency (Gaura Sub-District) dan Sumba Tengah (Ole Ate Sub-District)," 2012.

[9] Masrizal, "Filariasis Disease," J. Kesehat. Masy., vol. 7, no. 1, pp. 32-38, 2013.

[10] D. Haryuningtyas and D. T. Subekti, "Filariasis Dynamics in Indonesia," Lokakarya Nasional Penyakit Zoonosis. pp. 242-250, 2004.

[11] A. Gunn and S. J. Pitt, Parasitology An Integrated Approach, 6th ed. Wiley-Blackwell, 2012.

[12] DIT.JEND.PPM \& PL, "Pedoman Ekologi dan Aspek Perilaku Vektor." Health Department of the Republic of Indonesia, p. 25, 2004.

[13] Nasrin, "Environmental and Behavioral Factors Related to the Case of Filariasis In west Bangka Regency," Program Pascasarjana Universitas Diponogoro Semarang, 2008.

[14] Santoso, H. Sitorus, and R. Oktarina, "Risk Factors Filariasis Muaro Jambi Regency," Bul. Penelit. Kesehat, vol. 41, no. 3, pp. 152-162, 2013.

[15] T. A. Garjito, Jastal, Rosmini, H. Anastasia, Y. Srikandi, and Y. Labatjo, "Filariasis and Some Factors Related With Its Transmission In Pangku-Tolole Village, Ampibabo Sub-District, District Of Parigi-Moutong, Central Sulawesi Province," Vektora, vol. 5, no. 2, pp. 54-65, 2013.

[16] Santoso, "Relationship of Environmental Conditions to Filariasis Cases in Community ( An Advanced Analysis of Basic Health Research 2007 )," Aspirator, vol. 3, no. 1, pp. 1-7, 2011.

[17] I. A. Windiastuti, Suhartono, and Nurjazuli, "The Association between Environmental House Condistion , Socio-economic , and Behaviour Factors with Filariasis Occurance in South Pekalongan Sub-District, Pekalongan City,” J. Kesehat. Lingkung. Indones., vol. 12, no. 1, pp. 51-57, 2013.

[18] D. M. Sukatendra and M. A. Shidqon, "Description of Feeding Behavior of Culex sp. as Filariasis Vector Wuchereria Bancrofti," J. Pena Med., vol. 6, no. 1, pp. 19-33, 2016.

[19] P. Juriastuti, M. Kartika, I. M. Djaja, and D. Susanna, "Risk Factors of Filariasis in Jati Sampurna Village," Makara Kesehat., vol. 14, no. 1, pp. 31-36, 2010.

[20] I. A. Roziyah, "Relation of physical condition of the environment and people's behavior with the incidence of filariasis in the Padukuhan Kraton's Village Pekalongan City in 2015," Universitas Negeri Semarang, 2015.

[21] S. Novianti and A. Purwanto, "Influence of Preventive Behavior to Case of Filariasis in Tasikmalaya District," J. Kesehat. Komunitas Indones. Vol., vol. 8, no. 2, pp. 722-728, 2012.

[22] P. M. Davey, "The susceptibility of sorghum to attack by the weevil Sitophilus oryzae (L.)," 
Bull. Entomol. Res., vol. 56, no. 2, pp. 287-297, 1965.

[23] Anindita and H. Mutiara, "Filariasis : Prevention Related to Risk Factor," J. Kedokt. Unila, vol. 1, no. 2, pp. 1-6, 2016.

[24] S. A. Wulandhari and E. T. Pawenang, "Spatial Analysis Aspects of Environmental Health with Filariasis Occurance in pekalongan City," Unnes J. Public Heal., vol. 6, no. 1, pp. 59-67, 2017. 